\title{
The Mersilene Mesh Ptosis Sling
}

\author{
R. N. DOWNES ${ }^{1}$ and J. R. O. COLLIN ${ }^{2}$ \\ Aylesbury and London
}

\begin{abstract}
Summary
A variety of materials are currently available for use in brow suspension ptosis surgery when an alternative to autogenous fascia lata is indicated. We describe the use of a Mersilene mesh sling, developed to overcome the problems of failure and extrusion commonly associated with substitute suspensory materials. The results and follow up in 23 cases of blepharoptosis are presented. Our findings suggest that the Mersilene mesh sling has a definite place in ptosis management; we currently use this sling for all cases in which autogenous fascia lata is considered inappropriate.
\end{abstract}

Many different materials have been used in brow suspension ptosis surgery when an alternative to autogenous fascia lata is indicated. All have proved less than ideal because of unacceptably high failure rates and/or extrusion. ${ }^{1-3}$ The use of a non absorbable macromesh which becomes permanently incorporated into host tissues could in theory minimise these complications. One such material is Mersilene mesh, a flexible interwoven polyester fibre mesh. ${ }^{4}$ Multidisciplinary applications attest to the efficacy and safety of Mersilene mesh in clinical practice..$^{4-7}$

In oculoplastic surgery Mersilene mesh was originally employed as a lid spacer material, with favourable results. ${ }^{8}$ The mesh appears to be well tolerated by lid tissues. To date we have used Mersilene mesh slings in more than 30 patients requiring brow suspension ptosis surgery. Our initial findings were outlined in $1988 ;{ }^{9}$ the results and follow up of the first 23 cases are presented in this paper.

\section{Materials and Methods}

The Mersilene sling has been used in the management of 11 ptotic eyelids in eight chil- dren and 12 ptotic eyelids in seven adults. The aetiology of the blepharoptosis was chronic progressive external ophthalmoplegia (CPEO) in six patients, congenital ptosis in five children, 3rd nerve palsy in three patients and trigemino-oculomotor synkinesis (Marcus-Gunn phenomenon) in one child. All patients had severe ptosis with occlusion of the visual axis. Levator function was minimal (less than $4 \mathrm{~mm}$ of vertical lid excursion from downgaze to upgaze) in all cases. All but one of the children required early surgery to prevent or minimise amblyopia. One older child requested cosmetic ptosis surgery. Surgery was indicated for functional reasons in the adult patients. Previous surgery using stored fascia lata had failed in four cases, all within three months; levator surgery had been previously successful for several years in one adult.

Surgery was performed under general anaesthesia in the children; local anaesthesia was used in the remainder of cases. The surgical technique has been described previously ${ }^{9}$ using a modification of the method originally described by Fox. ${ }^{10}$ Stab incisions

${ }^{1}$ Princess Mary's Hospital, RAF Halton, Aylesbury and ${ }^{2}$ Moorfields Eye Hospital, London. Correspondence to Sqd Ldr R. N. Downes FRCS FCOphth, Princess Mary's Hospital, RAF Halton, Aylesbury, Bucks. 
were made in the eyelid and eyebrow, the former at the height of the contra lateral skin crease (if present) to ensure symmetry. Two equally spaced eyelid incisions were made through skin and orbicularis muscle to the tarsal plate, with a lid guard in place. Medial and lateral brow incisions were placed at the superior border of the eyebrow directly above the respective canthal angles with positioning of the superior incision midway between these two, $1 \mathrm{~cm}$ above the brow. The incisions were made through frontalis being wide enough to allow passage of a Wright's fascial needle.

The sling ( $15 \mathrm{~cm}$ long by $5-8 \mathrm{~mm}$ wide) was cut from a sheet of Mersilene mesh as shown in Fig. 1, then packed and autoclaved. It was cut so that the long axis ran parallel with the long axis of the individual mesh-pore configuration. Immediately prior to use the sling was soaked in a suitable antibiotic solution for several minutes (gentamycin or framycetin) then washed thoroughly in saline. Using a Wright's fascial needle, the sling was positioned deep to frontalis and orbicularis in the eyelid (Fig. 2) and the ends pulled tight. When the required lid height was attained the two strips of emergent mesh were sutured together with $5 / 0$ Ethibond just within the brow incision, excess mesh was trimmed and the sling allowed to retract into the forehead tissues (Fig. 3). The brow incisions were closed using either 6/0 Catgut sutures in the young children or $6 / 0$ Nylon sutures in the remainder of patients. It was not necessary to suture the eyelid incisions. A Frost suture was used if a risk of immediate post-operative exposure was felt likely. Oral broad spectrum antibiotics (cephalexin 62.5-500 mg tds) were routinely prescribed and topical antibiotics and lubricants used as required.

\section{Results}

The individual surgical results are detailed in Table I. Early post operative measurements were taken within one week of surgery; in all cases a significant improvement in lid height was achieved. The improvement, as assessed by pre-operative and post-operative vertical palpebral aperture measurements, ranged from 2 to $5 \mathrm{~mm}$ and averaged $3.5 \mathrm{~mm}$. Measurements were variable in some of the patients as a result of poor co-operation, variable frontalis action and the underlying disease process. In these cases an average reading was recorded. The initial post-operative lid positions have been maintained in all but one case over a follow-up period of 12-18 months (mean 15 months).

Pre-operative and post-operative orthoptic evaluation showed either an improvement in, or stabilisation of, the visual status in patients nine to 15 . There were no cases of mesh extrusion. Figures 4-7 are representative.

\section{Complications}

One significant complication occurred in this series. Patient 6 developed a post-operative preseptal cellulitis. This case was complicated by two factors. Systemic antibiotics were inadvertently omitted post operatively and the patient had an early, probably sub clinical, chest infection at the time of surgery. Sputum and lid swab cultures revealed the same infective organism (B Haemolytic Streptococcus). The infection resolved fully with appropriate systemic antibiotics. Removal of the mesh was not necessary. The lid height immediately following surgery was $6 \mathrm{~mm}$; it has remained at about $4 \mathrm{~mm}$, with maximal frontalis overaction, since this localised cellulitis. Three

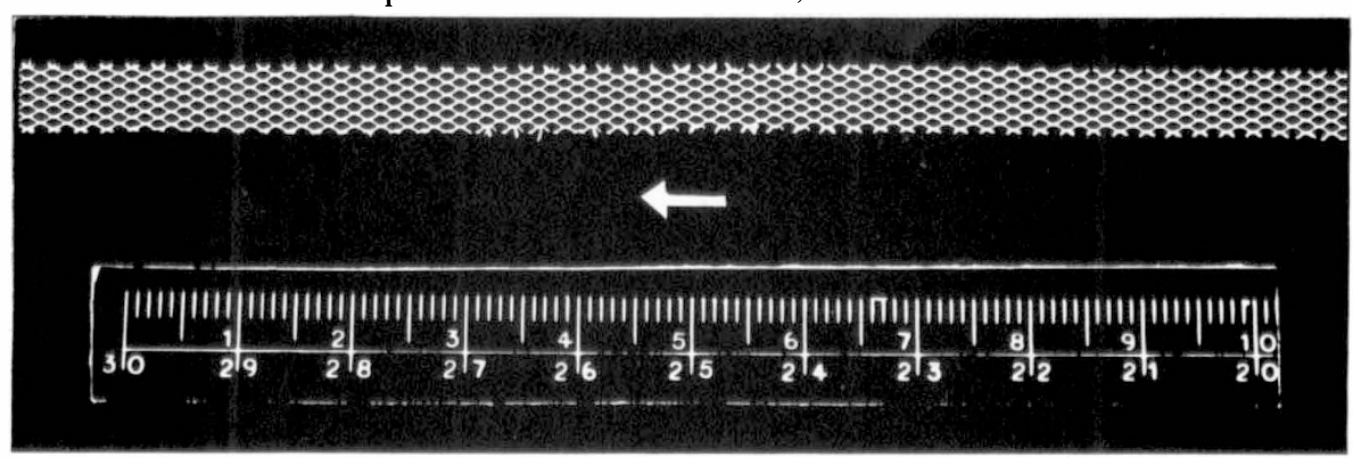

Fig. 1 The Mersilene mesh sling. Arrows indicate long axis of sling. 


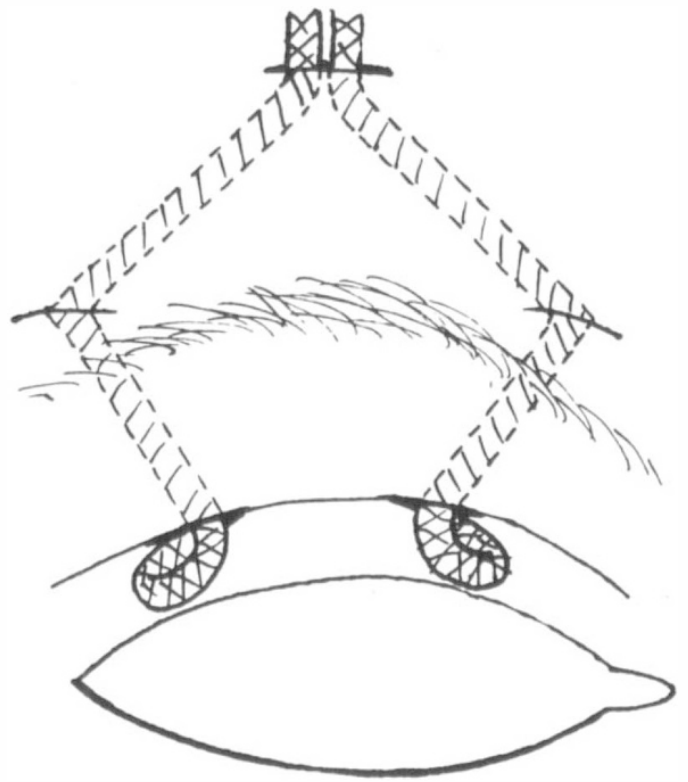

Fig. 2 Diagram illustrating sling in position prior to adjustment and fixation.

patients with CPEO developed mild exposure keratitis post operatively. All were successfully managed with topical lubricants and two of these patients continue to use lubricant drops as required.

\section{Discussion}

It is well recognised that occlusion of the visual axis by a ptotic upper eyelid in infancy and early childhood may lead to sensory deprivation amblyopia with or without strabismus. ${ }^{2,11}$ Ptosis also markedly influences vision, after maturation of the visual pathways, if severe enough to partially or totally occlude the visual axis. In each of these situations ptosis surgery is indicated, often as a matter of some urgency. Fourteen of the patients in this series were grouped into one or other of these categories. Correction of severe ptosis may also be requested for cosmetic reasons as exemplified by patient 8 .

To achieve satisfactory correction of severe blepharoptosis associated with minimal levator function, brow suspension surgery is invariably necessary. ${ }^{2,3,12}$ Whilst general agreement exists regarding the indications for brow suspension surgery, there is no such common concensus concerning the suspen- sory material used. Autogenous fascia lata is regarded as the best available material for brow suspension surgery but it is not without disadvantages. ${ }^{1-3,12}$ General anaesthesia is usually required for fascial harvesting and the patient's leg needs to be a certain size before adequate fascia can be taken. A separate procedure, which in itself can be time consuming and not without risks, is necessary at a site anatomically unfamiliar to most ophthalmologists. There are good reasons therefore to consider alternative suspensory materials in certain cases. Grafts of preserved fascia, skin, muscle and sclera as well as a host of synthetic materials including metallic implants, silicone rods, supramid, silk and polyester sutures, and more recently Gore-tex, all have their proponents. ${ }^{1-3,12,13}$ All these materials have certain disadvantages in terms of failure and/or extrusion. Theoretically, permanent tissue fixation of a sling material should minimise these complications. The concept of an open mesh which is integrated into the host tissue is an extension of this premise. A variety of macromeshes are currently available to the surgeon. Mersilene mesh would appear to be the most appropriate in the clinical setting of ptosis surgery. ${ }^{8,9}$ Mersilene mesh is a machine knitted interlocking polyester fibre mesh ${ }^{4}$ which has been used for many years in orthopaedic, gynaecological, general and vascular surgery. ${ }^{4-6}$ Animal and sub-

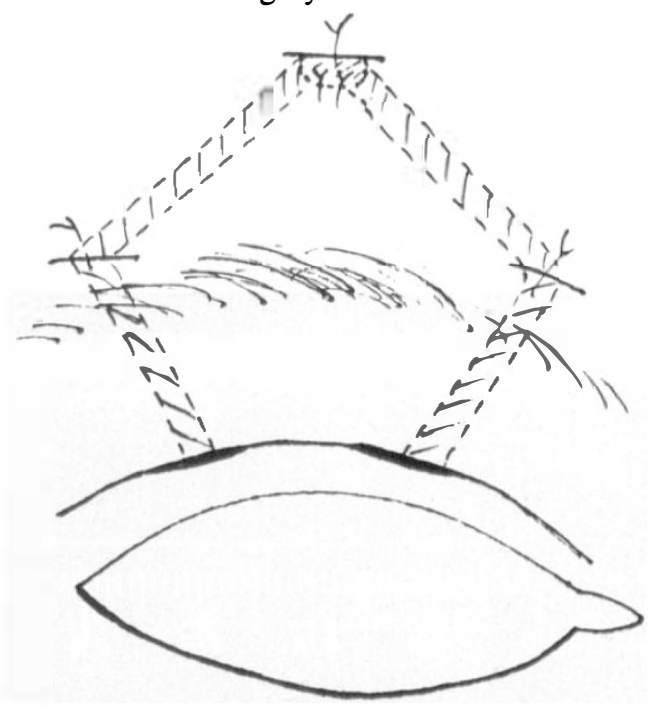

Fig. 3 Diagram illustrating final position of sling. 
Table I Patient details with pre and post operative lid height measurements

\begin{tabular}{|c|c|c|c|c|c|c|c|c|}
\hline \multirow[b]{2}{*}{ Patient } & \multirow[b]{2}{*}{ Sex } & \multirow[b]{2}{*}{ Age } & \multirow[b]{2}{*}{ Diagnosis } & \multirow[b]{2}{*}{ Eyelid } & \multicolumn{3}{|c|}{ Lid height $(\mathrm{mm})^{*}$} & \multirow{2}{*}{$\begin{array}{c}\text { Follow } \\
\text { up } \\
\text { (months) }\end{array}$} \\
\hline & & & & & Pre op & $\begin{array}{c}\text { Early } \\
\text { post op }\end{array}$ & $\begin{array}{c}\text { Final } \\
\text { post op }\end{array}$ & \\
\hline \multirow[t]{2}{*}{ 1. FM } & \multirow[t]{2}{*}{$\mathbf{M}$} & \multirow[t]{2}{*}{61} & \multirow[t]{2}{*}{ Oculopharyngeal dystrophy } & RIGHT & 3 & 7 & 7 & 16 \\
\hline & & & & LEFT & 3 & 6 & 7 & 14 \\
\hline \multirow[t]{2}{*}{ 2. IW } & \multirow[t]{2}{*}{$\mathrm{F}$} & \multirow[t]{2}{*}{65} & \multirow[t]{2}{*}{ CPEO } & RIGHT & $1 / 2$ & 5 & 5 & 17 \\
\hline & & & & LEFT & 2 & 5 & 5 & 15 \\
\hline \multirow[t]{2}{*}{ 3. MD } & \multirow[t]{2}{*}{$\mathbf{M}$} & \multirow[t]{2}{*}{58} & \multirow[t]{2}{*}{ Myotonic dystrophy } & RIGHT & 4 & 9 & 9 & 18 \\
\hline & & & & LEFT & 4 & 8 & 8 & 13 \\
\hline 4. FB & $\mathbf{M}$ & 68 & Oculopharyngeal dystrophy & LEFT & 4 & 6 & 7 & 14 \\
\hline \multirow[t]{2}{*}{ 5. $\mathrm{BL}$} & \multirow[t]{2}{*}{$\mathrm{F}$} & \multirow[t]{2}{*}{76} & \multirow[t]{2}{*}{ Oculopharyngeal dystrophy } & RIGHT & 3 & 6 & 7 & 13 \\
\hline & & & & LEFT & 3 & 7 & 7 & 14 \\
\hline \multirow[t]{2}{*}{ 6. PL } & \multirow[t]{2}{*}{$\mathbf{M}$} & \multirow[t]{2}{*}{58} & \multirow[t]{2}{*}{ Oculopharyngeal dystrophy } & RIGHT & 4 & 8 & 9 & 15 \\
\hline & & & & LEFT & 2 & 6 & 4 & 18 \\
\hline 7. $\mathrm{FE}$ & $\mathbf{M}$ & 42 & III N palsy & LEFT & 3 & 7 & 8 & 12 \\
\hline 8. $\mathrm{LH}$ & $\mathbf{M}$ & 14 & $\begin{array}{l}\text { Cyclic } \\
\text { III N palsy }\end{array}$ & RIGHT & 5 & 7 & 8 & 12 \\
\hline 9. SS & $\mathrm{F}$ & 3 & III N palsy & RIGHT & 3 & 7 & 7 & 12 \\
\hline \multirow[t]{2}{*}{ 10. JK } & $\mathbf{M}$ & $3 / 12$ & Congenital & RIGHT & 1 & 5 & 6 & 12 \\
\hline & & & ptosis & LEFT & 2 & 6 & 6 & 12 \\
\hline 11. CM & $\mathrm{F}$ & $4 / 12$ & Congenital & RIGHT & 2 & 5 & 6 & 17 \\
\hline & & & ptosis & LEFT & 2 & 5 & 6 & 17 \\
\hline 12. $\mathrm{TE}$ & $\mathrm{F}$ & 4 & $\begin{array}{l}\text { Congenital } \\
\text { ptosis }\end{array}$ & RIGHT & 2 & 5 & 5 & 16 \\
\hline 13. BT & $\mathbf{M}$ & 2 & $\begin{array}{l}\text { Congenital } \\
\text { ptosis }\end{array}$ & LEFT & 2 & 7 & 7 & 17 \\
\hline 14. $\mathrm{CF}$ & $\mathrm{F}$ & 2 & Blepharophimosis & RIGHT & 2 & 6 & 51 & 13 \\
\hline & & & & LEFT & 2 & 5 & $5 j$ & 13 \\
\hline 15. ES & $\mathbf{M}$ & 1 & $\begin{array}{l}\text { Marcus-Gunn } \\
\text { phenomenon }\end{array}$ & LEFT & $1-3$ & $4-8$ & $4-7$ & 17 \\
\hline
\end{tabular}

*Lid height expressed as the vertical palpebral aperture in millimetres.

sequent clinical studies have shown that this macromesh acts as a permanent scaffold which supports significant fibrovascular ingrowth. ${ }^{4-6,8,14}$ We have recently seen evidence of this permanent tissue incorporation, having re-operated on one patient (not included in this series since the follow up was less than three months) in whom a satisfactory lid height was not achieved from the outset with a Mersilene sling. At operation the mesh was firmly integrated into the lid and brow tissue such that removal was not possible without extensive and clinically inappropriate surgery. Figure 8 is a photomicrograph of a portion of excised mesh which clearly shows ingrowth of fibrovascular tissue within the mesh structure. A successful repeat Mersilene sling procedure has since been performed in this case.

The results show a significant improvement in lid height which has been sustained in all but one patient over a minimum period of 12 months. In terms of conventional ptosis surgery the improvement in eyelid height in some cases might appear less than ideal. In a number of patients we aimed for adequate as opposed to maximal eyelid elevation. Patients with severe CPEO have a poor Bell's phenomenon coupled with poor lid closure. If ptosis is 'fully' corrected in these cases significant problems from corneal exposure will almost certainly ensue. ${ }^{15}$ To date no patients have developed this problem.

The only significant complication encountered was a post operative preseptal cellulitis of the left eyelid in patient 6 . The infection settled fully using appropriate systemic antibiotic therapy; removal of the mesh was not necessary. It is possible, under these circumstances, that this complication could have arisen with any suspensory material. Successful surgery using a Mersilene sling has since 


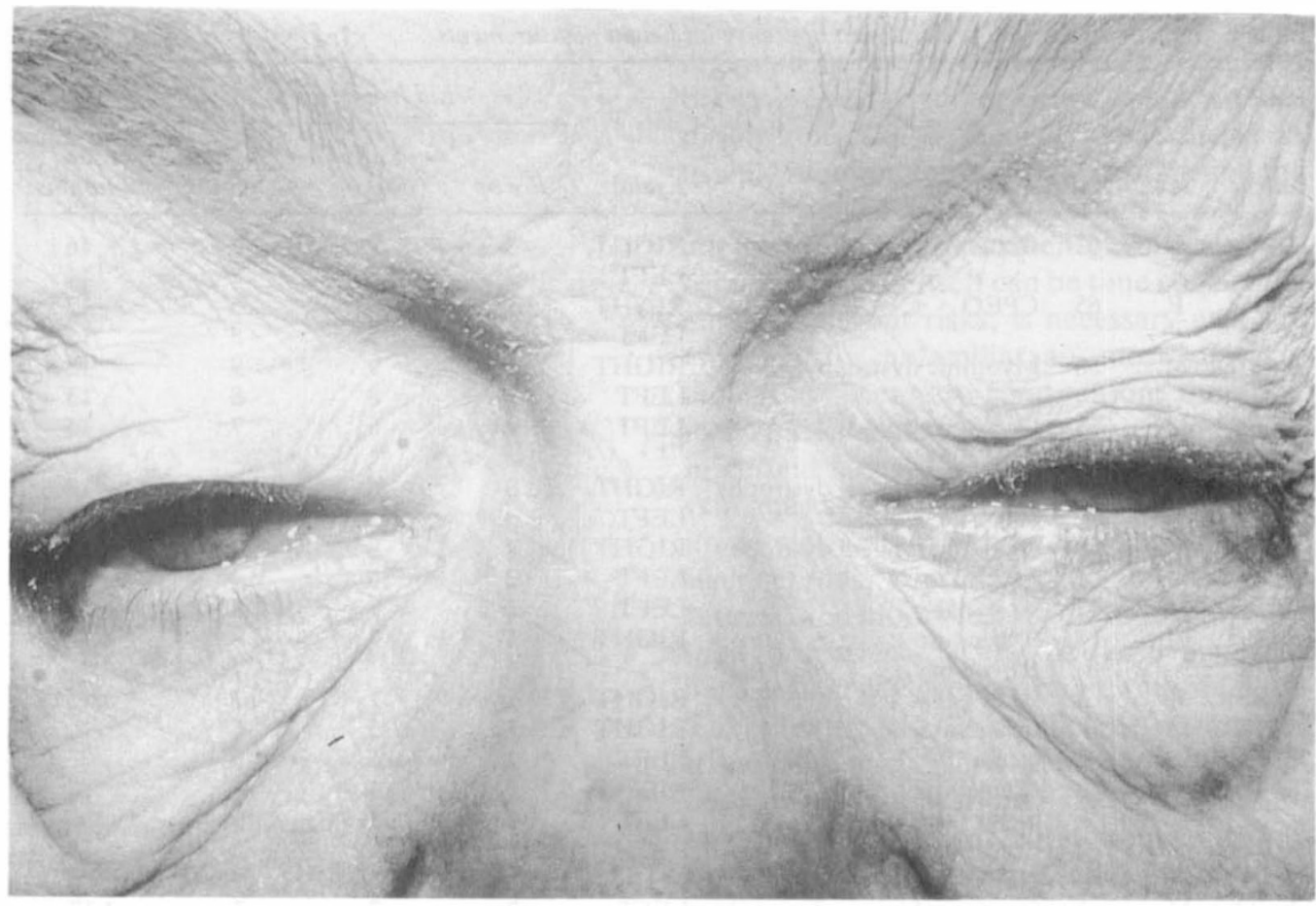

Fig. 4 Patient 5-with chronic progressive external ophthalmoplegia and severe bilateral ptosis-pre-operatively.

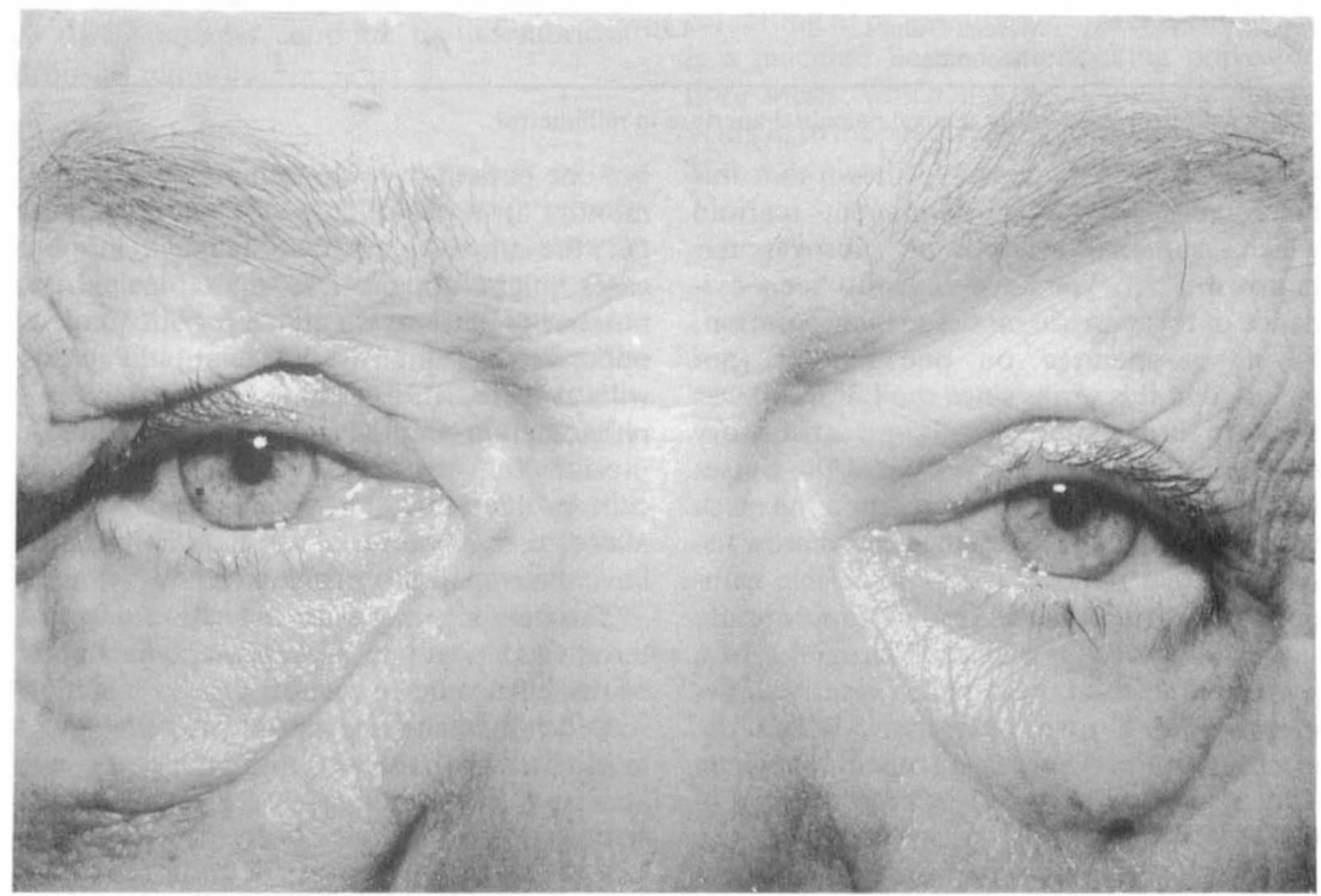

Fig. 5 Patient 5-Post operative appearances 3 months after bilateral Mersilene mesh slings. 


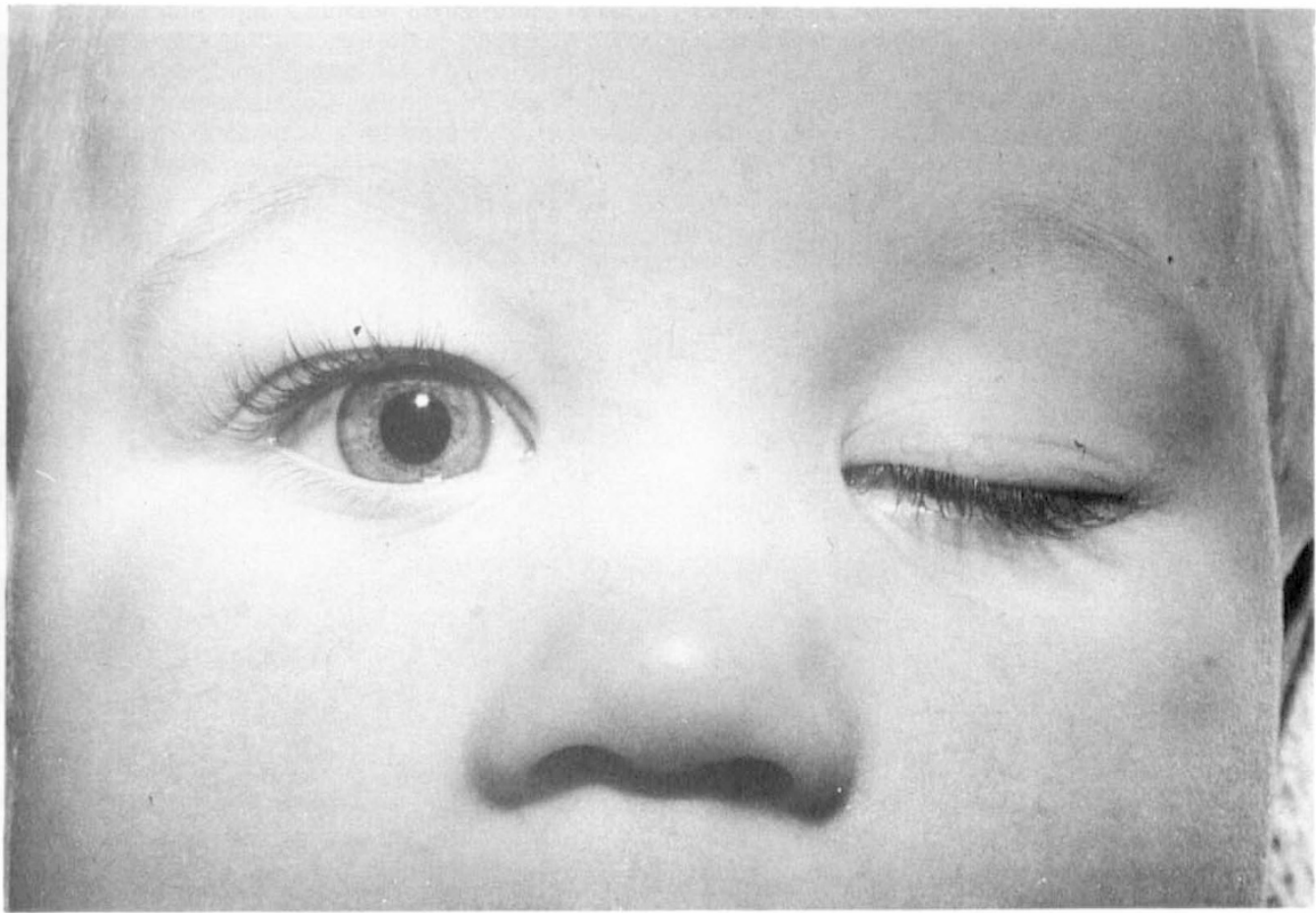

Fig. 6 Patien 1.3-with severe unilateral congenital prosis-pre-operatively.

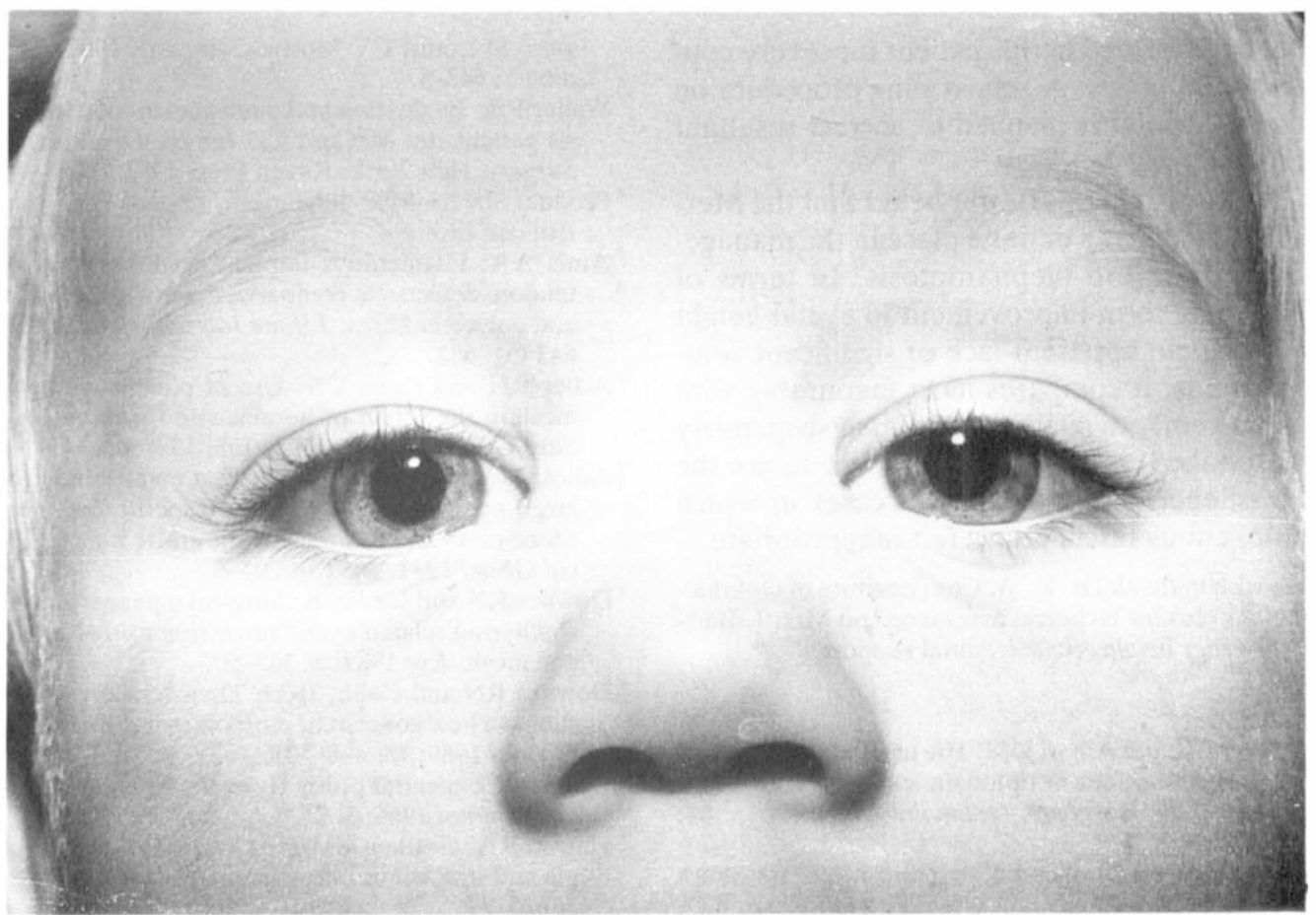

Fig. 7 Patient 13-post operative appearances 6 months following unilateral left Mersilene mesh sling. 


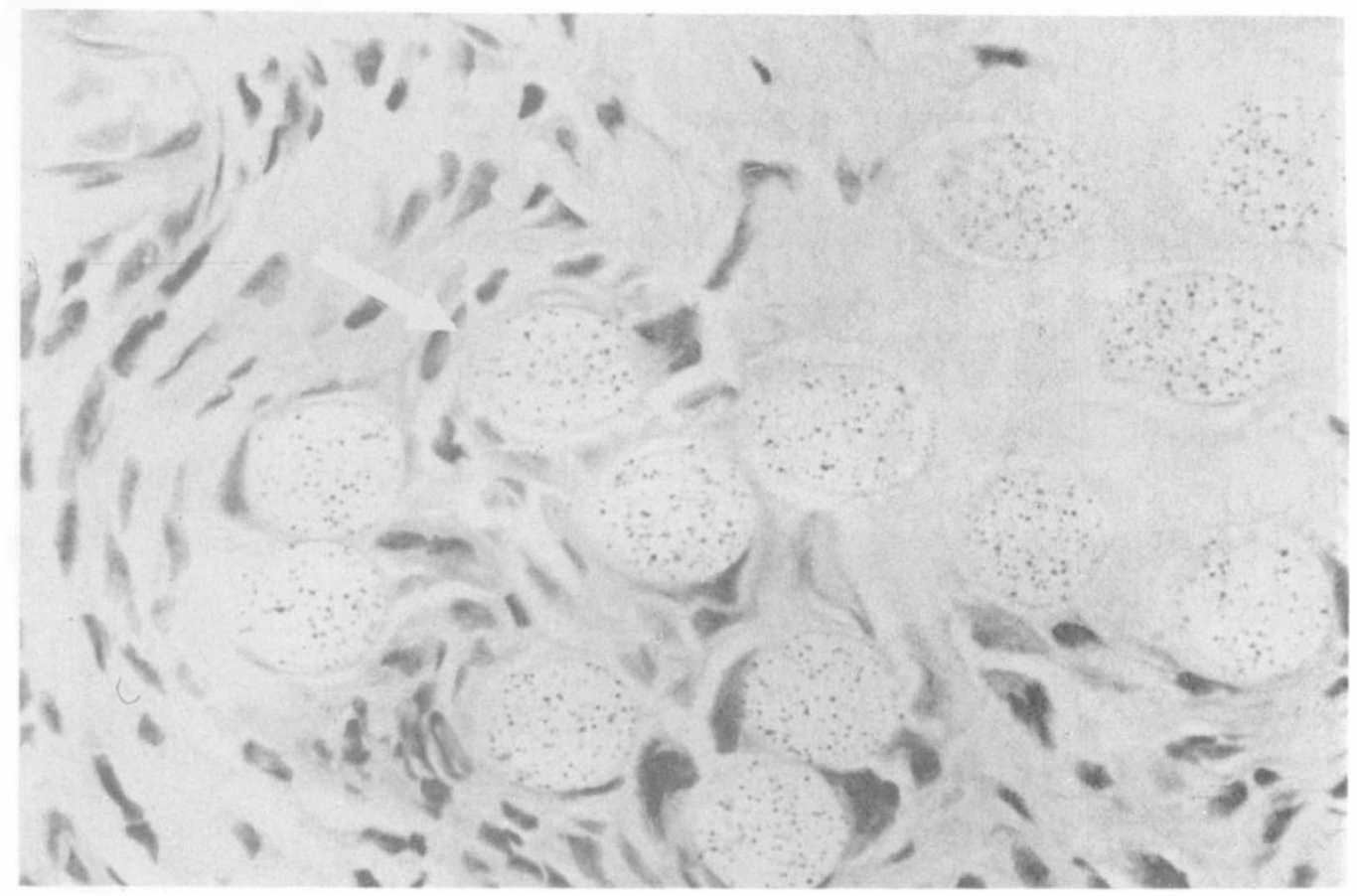

Fig. 8 Photomicrograph demonstrating individual mesh fibres (arrowed) with intimate fibrovascular ingrowth. (haematoxylin-eosin stain; original magnification $\times 160$ ).

been performed in this patient for severe contralateral ptosis. A repeat sling procedure on the left eyelid is planned to correct resultant lid asymmetry.

This study supports our belief that the Mersilene sling has a definite place in the management of severe blepharoptosis. In terms of both long term improvement in eyelid height allied to an apparent lack of significant complications, it compares most favourably with all currently available alternative suspensory materials. It is our current practice to use the Mersilene mesh sling for all cases in which autogenous fascia lata is felt inappropriate.

We wish to thank Dr. R. W. Cox (Institute of Ophthalmology) for his technical assistance and Mrs. J. Bartlett for her invaluable secretarial support.

\section{References}

${ }^{1}$ Beyer CK and Albert DM: The use and fate of fascia lata and sclera in ophthalmic plastic and reconstructive surgery. Ophthalmology 1981, 88: $869-86$

${ }^{2}$ Crawford JS: Congenital blepharoptosis. In: Smith BV, Della Rocca RC, Nesi FA and Lisman RD, eds. Ophthalmic Plastic and Reconstructive Sur- gery. St Louis: CV Mosby Company, 1987: Volume 1 ; 643-5.

${ }^{3}$ Waller RR: Evaluation and management of the ptosis patient. In: McCord CD Jnr ed. Oculoplastic Surgery. New York: Raven Press 1982: 60-8.

${ }^{4}$ Product Sheet-Mersilene mesh; revised 9/85 from Ethicon Ltd.

${ }^{5}$ Amis AA: Filamentous implant reconstruction of tendon defects: a comparison between carbon and polyester fibres. J Bone Joint Surg (Br) 1982; 643 (5): 682.

${ }^{6}$ Adler RH and Fume CN: Use of pliable synthetic mesh in the repair of hernias and tissue defects. Surg Gynecol Obstet 1959; 108: 199-206.

${ }^{7}$ Adloff $M$ and Arnaud JP: Surgical management of large incisional hernias by an intraperitoneal Mersilene mesh and an aponeurotic graft. Surg Gynecol Obstet 1987; 165 (3): 204-6.

${ }^{8}$ Downes RN and Jordan K: Surgical management of dysthyroid related eyelid retraction using Mersilene mesh. Eye 1989: 3: 385-90.

${ }^{9}$ Downes RN and Collin JRO: The Mersilene mesh sling-a new concept in ptosis surgery. $\mathrm{Br} \mathrm{J} \mathrm{Oph-}$ thalmol 1989; 73: 498-501.

${ }^{10}$ Fox SA: Congenital ptosis II. Frontalis sling. J Ped Ophthalmol 1966; 3: 25.

${ }^{11}$ Harrad RA, Graham CM and Collin JRO: Amblyopia and strabismus in congenital ptosis. Eye 1988; 2: 625-7.

${ }^{12}$ Collin JRO: A manual of systematic eyelid surgery. 
1st ed. Edinburgh. Churchill Livingstone, 1983: 60-74.

${ }^{13}$ Morax S, Bok C and Ruban JM: Use of Gore-tex (PTFE) in ophthalmic plastic surgery. Presented to French Ophthalmological Society. Paris, May 1987. Ophthalmology (in Press).
${ }^{14}$ Peyman GA, Koziol J and Janevicins R: Intraocular lens fixation with Dacron mesh: part II. Ophthalmic Surg 1977; 8: 87-93.

${ }^{15}$ Lane CM and Collin JRO: Treatment of ptosis in chronic progressive external ophthalmoplegia. $\mathrm{Br}$ J Opthalmol 1987; 71: 290-4. 